\title{
A STUDY OF THE EFFECT OF MUSCULAR EXERCISE WITH CINNAMON EXTRACT AND/OR FLAXSEEDS EXTRACT ON DIABETIC ADULT MALE ALBINO RATS
}

\author{
By \\ Mahmoud Ahmed Mohamed, Gamal Ahmed Shawer and Al-Bayoumi \\ Ali Fouda
}

Department of Medical Physiology, Al-Azhar Faculty of Medicine

\begin{abstract}
Background: Diabetes is one of the most common endocrine disorders. Muscular exercise possesses antioxidant property and can be a candidate in the treatment and prevention of diabetes complications. Cinnamon is a plant which displays antioxidant and glucose lowering effects. Flaxseeds are a promising alternative to reduce the risk of diseases associated with increased body weight as diabetes mellitus.
\end{abstract}

Objective: To study the effect of muscular exercise with cinnamon extract and/or flaxseeds extract on diabetic adult male albino rats.

Materials and Method: The present study was conducted on 72 adult male albino rats of a local strain divided into 9 equal groups:

Group I: Control received distilled water only.

Group II: Treated with flaxseeds extract ( $400 \mathrm{mg} / \mathrm{kg}$ orally).

Group III: Treated with cinnamon extract (200 mg/kg orally).

Group IV: Control practiced swimming program.

Group V: Diabetic control rats.

Group VI: Diabetic rats practiced swimming program.

Group VII: Diabetic practiced swimming program and received flaxseeds extract.

Group VIII: Diabetic practiced swimming program and received cinnamon extract.

Group IX: Diabetic practiced swimming program and received both flaxseeds and cinnamon extract.

Rats submitted to swimming program, received flaxseeds and cinnamon extracts after induction of diabetes according to the study groups, and submitted to body weight and food consumption assessment. At the end of the study, fasting plasma glucose level, blood insulin level, HbAlc, lipid profile, reduced glutathione (GSH) and malondialdehyde (MDA) were measured.

Results: In diabetic rat's submitted to swimming and received flaxseeds and cinnamon extracts, body weight relative to food consumption decreased. Fasting plasma glucose level and blood insulin level improved. No change in HBA1c. Lipid profile improved, reduced glutathione (GSH) increased in flaxseeds and cinnamon diabetic groups. Malondialdehyde (MDA) decreased in swimmed, flaxseeds and cinnamon diabetic groups. Histo-pathological architecture improved. The effect of combination of swimming, flaxseeds and cinnamon improved all parameters.

Conclusion: Exercise with receiving flaxseeds extract or cinnamon extract in adult male diabetic rats improve body weight, glucose and insulin level, lipid profile, oxidative stress markers and tissue pathology, and the combination was more potent than each one alone. 
Key words: Exercise - Cinnamon - Flaxseeds - Diabetes Mellitus.

\section{INTRODUCTION}

Diabetes mellitus is a metabolic disease characterized by hyperglycemia resulting from defects in insulin secretion, insulin resistance, or both. The chronic hyperglycemia of diabetes is associated with long term damage, dysfunction and failure of various organs (Asano et al., 2014).

Among various forms of treatments for diabetes mellitus, exercise training which have been shown to possess an encouraging antioxidant property and can be a valuable candidate in the treatment and prevention of diabetes complications (Kaviarasan, 2015).

Cinnamon is dietary component that has been shown to contain biologically active substances that regulate blood glucose by insulin-mimetic properties, which enhances glucose uptake by activating insulin receptor kinase activity, auto-phosphorylation of the insulin receptor and has anti-oxidant effect (Salima et al., 2018).

Flaxseeds showed distinctive antiinflammatory, analgesic, and anti-oxidant action against variety of agents. Their anti-oxidant effect has blood glucose and body weight regulating action (Hasaniani et al., 2019).

The present work aimed to study the effect of muscular exercise with cinnamon extract and/or flaxseeds extract on diabetic adult male albino rats.

\section{MATERIALS AND METHODS}

Seventy two adult male albino rats of a local strain were chosen as an animal model for this study weighting 80-100 grams. Rats were purchased from Helwan Animal Farm (Cairo), and kept in suitable cages $(30 \times 32 \times 25 \mathrm{~cm}$ for every 5 rats) at room temperature, with the natural lightdark cycle in the animal laboratory of Medical Physiology Department, AlAzhar Faculty of Medicine.

They were fed on the standard rat food formula (El-Nasr-Pharmaceutical Co.) in addition to bread and green vegetables with free water supply. They kept for ten days to adapt the new conditions before starting the experiment. The study period was 8 weeks.

Rats submitted to swimming program, receiving flaxseeds and cinnamon extracts after induction of diabetes according to study groups, and submitted to body weight and food consumption assessment, and at the end of the study the following was done; measuring of fasting plasma glucose level, blood insulin level, HbA1c, lipid profile, reduced glutathione (GSH), malondialdehyde (MDA).

The swimming program: Rats in exercising groups (Groups IV, VI, VII, VIII and IX) were subjected to swimming in a swimming plastic barrel $(50 \mathrm{~cm}$ diameter with a depth of $50 \mathrm{~cm}$ ) half filled with tap water. Rats were given the chance to stay in water on the first day for 10 minutes /day till reaching $60 \mathrm{~min} /$ day on the sixth day to be familiar and adapted with water. The exercise protocol was continued for 5 days /week for 8 weeks after induction of diabetes (Estadella et al., 2004). 


\section{Statistical analysis:}

The data of the results were collected, tabulated and statistically managed by SPSS program: All results were presented as mean \pm SD. Mean value of the different groups was compared using Kruskal-
Wallis test. Least significant difference (LSD) post hoc analysis was used to identify significantly different mean value. $P$ value $\leq 0.05$ was considered significant.

\section{RESULTS}

When diabetic rats submitted to swimming and received flaxseeds and cinnamon extracts, body weight relative to food consumption was decreased (Tables 1 and 2). 


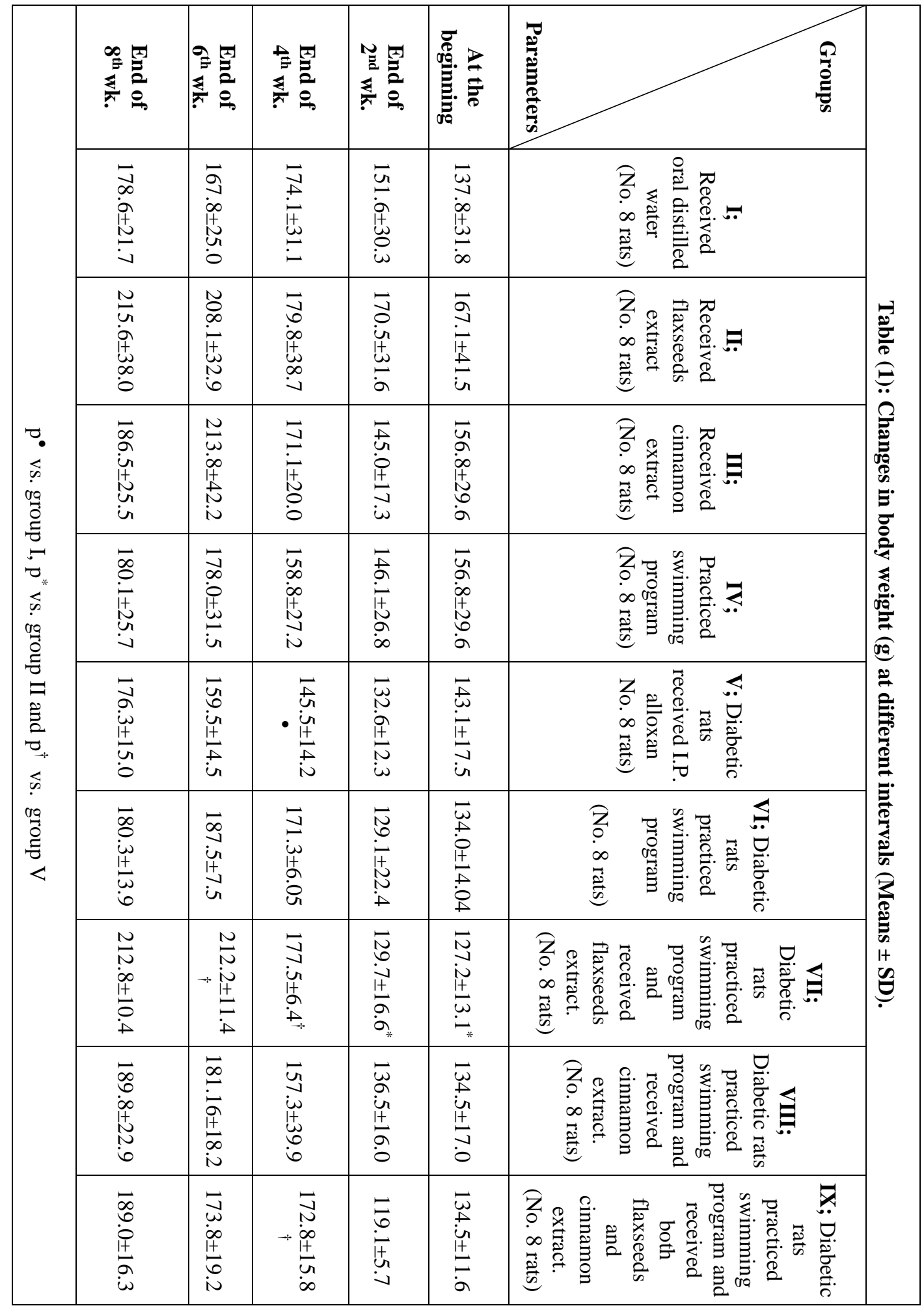


A STUDY OF THE EFFECT OF MUSCULAR EXERCISE WITH...

\begin{tabular}{|c|c|c|c|c|c|c|c|}
\hline \multirow{10}{*}{ 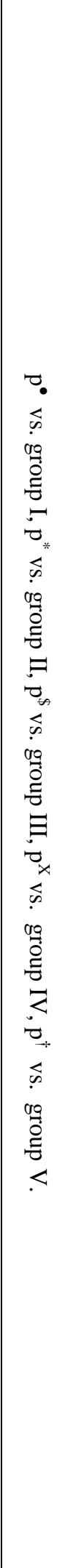 } & 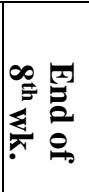 & 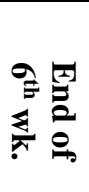 & 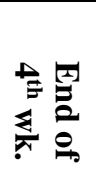 & 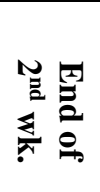 & 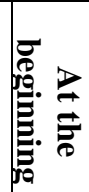 & $\frac{\Omega}{3}$ & \multirow{10}{*}{ 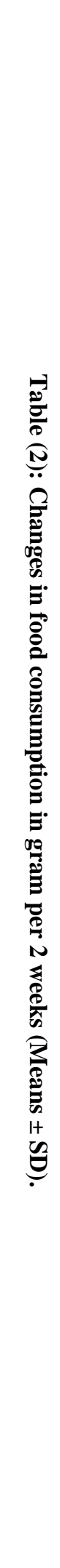 } \\
\hline & 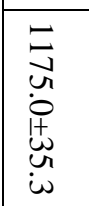 & 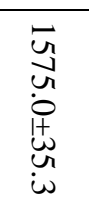 & 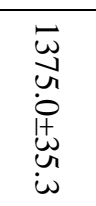 & 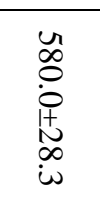 & $\begin{array}{l}w \\
\infty \\
0 \\
0 \\
i \\
1 \\
N \\
\infty \\
i\end{array}$ & 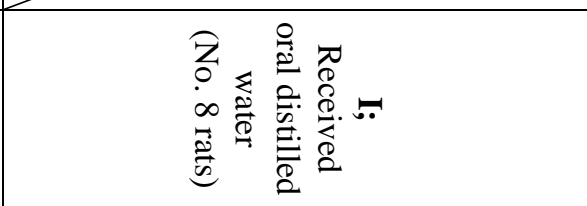 & \\
\hline & 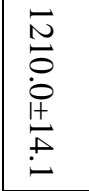 & $\begin{array}{l}\overline{\breve{r}} \\
\infty \\
0 \\
0 \\
\dot{1} \\
\infty \\
\infty \\
\text { i }\end{array}$ & 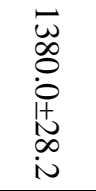 & 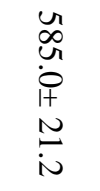 & 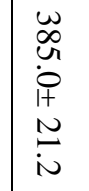 & 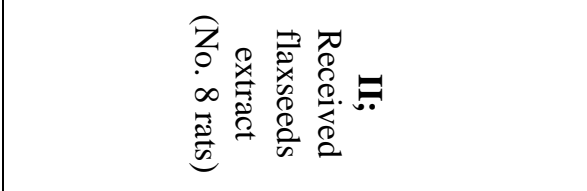 & \\
\hline & 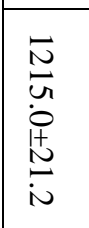 & 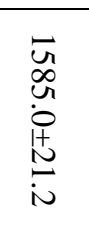 & 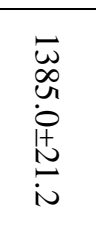 & 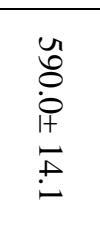 & 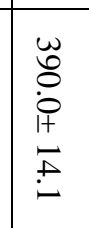 & 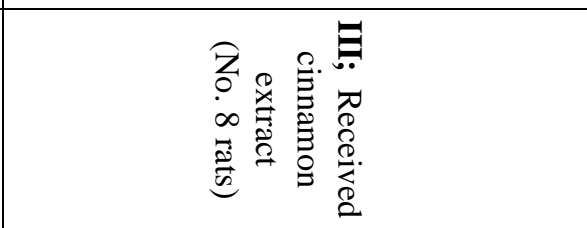 & \\
\hline & 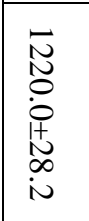 & 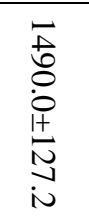 & 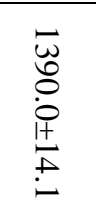 & 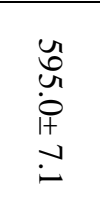 & 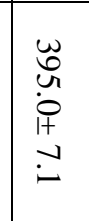 & 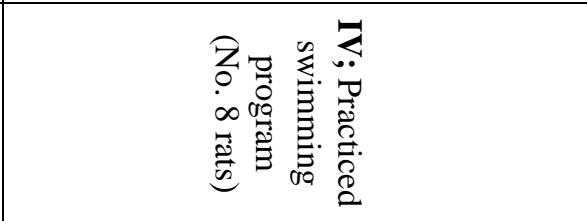 & \\
\hline & 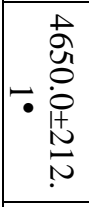 & 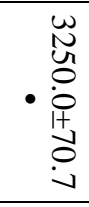 & 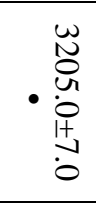 & 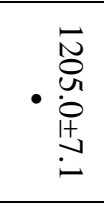 & 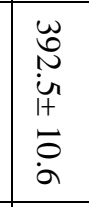 & 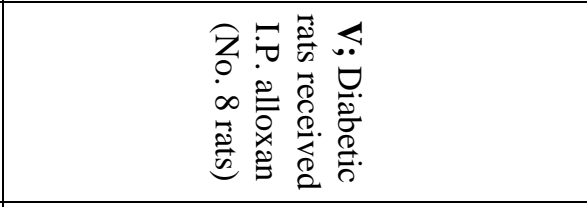 & \\
\hline & 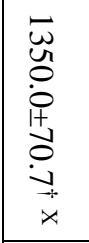 & 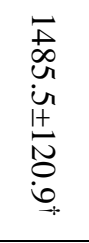 & 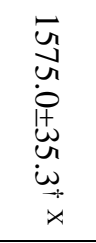 & $\begin{array}{l}\stackrel{N}{0} \\
\dot{0} \\
\dot{0} \\
\stackrel{+}{*} \\
\dot{H}_{x}\end{array}$ & $\begin{array}{l}\omega \\
\infty \\
\infty \\
0 \\
i \\
\sigma \\
\sigma \\
0\end{array}$ & 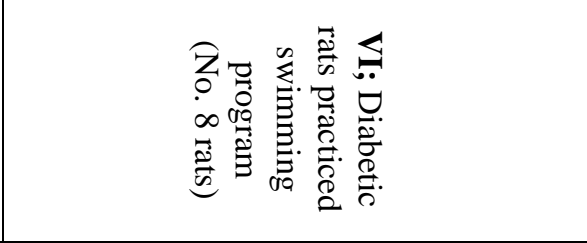 & \\
\hline & 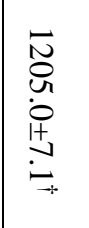 & 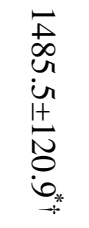 & 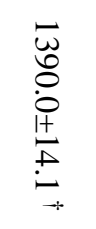 & 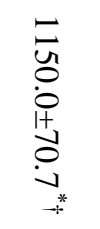 & 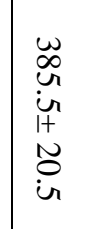 & 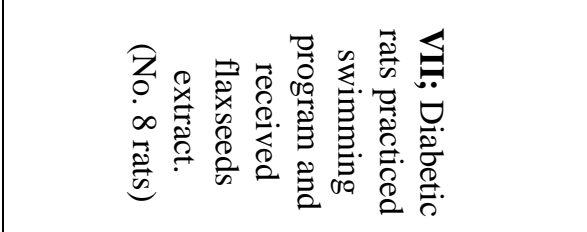 & \\
\hline & 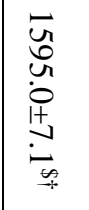 & 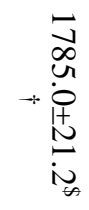 & 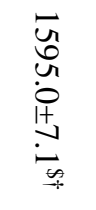 & 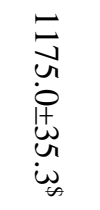 & 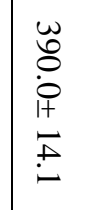 & 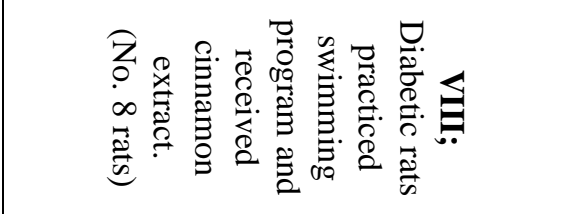 & \\
\hline & 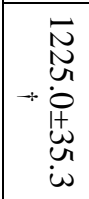 & 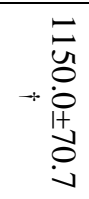 & 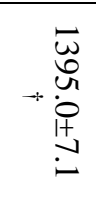 & 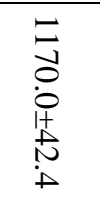 & 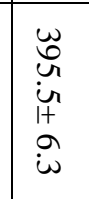 & 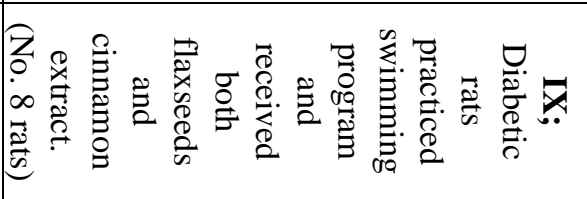 & \\
\hline
\end{tabular}


When diabetic rats submitted to swimming and received flaxseeds and cinnamon extracts, fasting plasma glucose level and blood insulin level improved without change in HBA1c (Table 3).

Table (3): Changes in fasting blood glucose level (FPGL), HBA1c, fasting insulin (Means \pm SD)

\begin{tabular}{|l|c|c|c|}
\hline \multicolumn{1}{|c|}{ Parameters } & $\begin{array}{c}\text { FPGL } \\
\text { Groups }\end{array}$ & $\begin{array}{c}\text { HBA1c } \\
(\%)\end{array}$ & $\begin{array}{c}\text { Fasting insulin level } \\
\text { (uIU/ml) }\end{array}$ \\
\hline $\begin{array}{l}\text { I; Received oral distilled water } \\
\text { (No. 8 rats) }\end{array}$ & $62.3 \pm 7.4$ & $3.7 \pm 0.6$ & $2.1 \pm 0.9$ \\
\hline $\begin{array}{l}\text { II; Received flaxseed extract } \\
\text { (No. 8 rats) }\end{array}$ & $65.8 \pm 5.1$ & $3.3 \pm 0.4$ & $3.0 \pm 0.6$ \\
\hline $\begin{array}{l}\text { III; Received cinnamon extract } \\
\text { (No. 8 rats) }\end{array}$ & $59.8 \pm 3.1$ & $4.2 \pm 2.3$ & $2.7 \pm 1.1$ \\
\hline $\begin{array}{l}\text { IV; Practiced swimming } \\
\text { program } \\
\text { (No. 8 rats) }\end{array}$ & $67.8 \pm 15.1$ & $3.8 \pm 1.11$ & $2.8 \pm 0.7$ \\
\hline $\begin{array}{l}\text { V; Diabetic rats received I.P. } \\
\text { alloxan } \\
\text { (No. 8 rats) }\end{array}$ & $242.9 \pm 39.5^{\bullet}$ & $4.6 \pm 0.7$ & $0.4 \pm 0.2^{\bullet}$ \\
\hline $\begin{array}{l}\text { VI; Diabetic rats practiced } \\
\text { swimming program } \\
\text { (No. 8 rats) }\end{array}$ & $147.6 \pm 30.8^{\mathrm{X} \dagger}$ & $3.9 \pm 0.4$ & $1.2 \pm 1.0^{\mathrm{X}}$ \\
\hline $\begin{array}{l}\text { VII; Diabetic rats practiced } \\
\text { swimming program and } \\
\text { received flaxseed extract } \\
\text { (No. 8 rats) }\end{array}$ & $123.2 \pm 20.1^{* \dagger}$ & $3.5 \pm 0.4$ & $1.4 \pm 0.8^{* \dagger}$ \\
\hline $\begin{array}{l}\text { VIII; Diabetic rats practiced } \\
\text { swimming program and } \\
\text { received cinnamon extract } \\
\text { (No. 8 rats) }\end{array}$ & $121.3 \pm 21.8^{\$ \dagger}$ & $3.7 \pm 0.6$ & $1.8 \pm 1.1^{\dagger}$ \\
\hline $\begin{array}{l}\text { IX; Diabetic rats practiced } \\
\text { swimming program and } \\
\text { received both flaxseed and } \\
\text { cinnamon extract } \\
\text { (No. 8 rats) }\end{array}$ & $94.0 \pm 16.5^{\dagger}$ & $3.5 \pm 0.4$ & $1.9 \pm 0.9^{\dagger}$ \\
\hline
\end{tabular}

$\mathrm{p} \bullet$ vs. group I, $\mathrm{p}^{*}$ vs. group II, $\mathrm{p} \$$ vs. group III, $\mathrm{pX}$ vs. group IV, $\mathrm{p} \dagger$ vs. group $\mathrm{V}$,.

When diabetic rats submitted to swimming and received flaxseeds and cinnamon extracts, lipid profile improved (Table 4). 
Table (4): Changes in lipid profile (Means \pm SD)

\begin{tabular}{|c|c|c|c|c|}
\hline $\begin{array}{ll}\text { Groups } & \text { Parameters } \\
\end{array}$ & $\begin{array}{c}\mathbf{T G} \\
(\mathbf{m g} / \mathbf{d l})\end{array}$ & $\begin{array}{c}\text { Cholesterol } \\
(\mathrm{mg} / \mathrm{dl})\end{array}$ & $\begin{array}{c}\text { LDL } \\
(\mathbf{m g} / \mathbf{d l})\end{array}$ & $\begin{array}{c}\text { HDL } \\
(\mathbf{m g} / \mathbf{d l})\end{array}$ \\
\hline $\begin{array}{l}\text { I; Received oral } \\
\text { distilled water } \\
\text { (No. } 8 \text { rats) }\end{array}$ & $97.8 \pm 14.5$ & $98.3 \pm 27.9$ & $37.7 \pm 8.5$ & $40.0 \pm 6.3$ \\
\hline $\begin{array}{l}\text { II; Received flaxseed } \\
\text { extract } \\
\text { (No. } 8 \text { rats) } \\
\end{array}$ & $73.7 \pm 14.1$ & $124.3 \pm 23.7$ & $39.0 \pm 8.5$ & $39.8 \pm 8.4$ \\
\hline $\begin{array}{l}\text { III; Received cinnamon } \\
\text { extract } \\
\text { (No. } 8 \text { rats) }\end{array}$ & $65.2 \pm 14.3$ & $108.0 \pm 20.9$ & $34.1 \pm 4.9$ & $37.5 \pm 15.1$ \\
\hline $\begin{array}{l}\text { IV; Practiced swimming } \\
\text { program } \\
\text { (No. } 8 \text { rats) }\end{array}$ & $83.3 \pm 23.5$ & $95.0 \pm 26.9$ & $35.3 \pm 11.5$ & $37.8 \pm 17.2$ \\
\hline $\begin{array}{l}\text { V; Diabetic rats } \\
\text { received I.P. alloxan } \\
\text { (No. } 8 \text { rats) }\end{array}$ & $123.9 \pm 25.9$ & $136.6 \pm 19.8^{\bullet}$ & $54.7 \pm 22.9^{\bullet}$ & $19.8 \pm 7.9^{\bullet}$ \\
\hline $\begin{array}{l}\text { VI; Diabetic rats } \\
\text { practiced swimming } \\
\text { Program } \\
\text { (No. } 8 \text { rats) }\end{array}$ & $123.6 \pm 40.2$ & $111.0 \pm 24.3^{\dagger}$ & $46.1 \pm 14.5$ & $29.1 \pm 8.9$ \\
\hline $\begin{array}{l}\text { VII; Diabetic rats } \\
\text { practiced swimming } \\
\text { program and received } \\
\text { flaxseed extract } \\
\text { (No. 8 rats) }\end{array}$ & $79.8 \pm 22.4^{\dagger}$ & $88.8 \pm 20.2^{* \dagger}$ & $35.4 \pm 11.5^{\dagger}$ & $47.4 \pm 19.8^{\dagger}$ \\
\hline $\begin{array}{l}\text { VIII; Diabetic rats } \\
\text { practiced swimming } \\
\text { program and received } \\
\text { cinnamon extract } \\
\text { (No. 8 rats) }\end{array}$ & $75.5 \pm 30.6^{\dagger}$ & $102.75 \pm 18.1^{\dagger}$ & $37.25 \pm 9.9^{\dagger}$ & $39.87 \pm 18.6^{\dagger}$ \\
\hline $\begin{array}{l}\text { IX; Diabetic rats } \\
\text { practiced swimming } \\
\text { program and received } \\
\text { both flaxseed and } \\
\text { cinnamon extract } \\
\text { (No. } 8 \text { rats) }\end{array}$ & $53.0 \pm 23.7^{\dagger}$ & $60.1 \pm 17.6^{\dagger}$ & $30.1 \pm 13.3^{\dagger}$ & $48.5 \pm 19.1^{\dagger}$ \\
\hline
\end{tabular}

p•vs. group I, p* vs. group II, p广 vs. group V.

When diabetic rats submitted to swimming and received flaxseeds and cinnamon extracts, reduced glutathione (GSH) increased in flaxseeds and cinnamon diabetic groups, and malondialdehyde (MDA) decreased in swimmed, flaxseeds and cinnamon diabetic groups (Table 5). 
Table (5): Changes in GSH and MDA (Means \pm SD).

\begin{tabular}{|c|c|c|}
\hline $\begin{array}{c}\text { Parameters } \\
\text { Groups } \\
\end{array}$ & $\begin{array}{c}\text { GSH } \\
(\mathrm{mmol} / \mathrm{g} . \mathrm{tissue})\end{array}$ & $\begin{array}{c}\text { MDA } \\
\text { (nmol/g.tissue) }\end{array}$ \\
\hline $\begin{array}{l}\text { I; Received oral distilled water } \\
\text { (No. } 8 \text { rats) }\end{array}$ & $1.15 \pm 0.154$ & $4.423 \pm 0.47$ \\
\hline $\begin{array}{l}\text { II; Received flaxseed extract } \\
\text { (No. } 8 \text { rats) }\end{array}$ & $1.08 \pm 0.32$ & $4.40 \pm 0.43$ \\
\hline $\begin{array}{l}\text { III; Received cinnamon extract } \\
\text { (No. } 8 \text { rats) }\end{array}$ & $1.16 \pm 0.41$ & $4.24 \pm 1.71$ \\
\hline $\begin{array}{l}\text { IV; Practiced swimming program } \\
\text { (No. } 8 \text { rats) }\end{array}$ & $1.29 \pm 0.31$ & $5.33 \pm 0.91$ \\
\hline $\begin{array}{l}\text { V; Diabetic rats received I.P. alloxan } \\
\text { (No. } 8 \text { rats) }\end{array}$ & $0.74 \pm 0.32$ & $28.26 \pm 5.97^{\bullet}$ \\
\hline $\begin{array}{l}\text { VI; Diabetic rats practiced swimming program } \\
\text { (No. } 8 \text { rats) }\end{array}$ & $1.14 \pm 0.55$ & $19.17 \pm 8.29^{\dagger \mathrm{X}}$ \\
\hline $\begin{array}{l}\text { VII; Diabetic rats practiced swimming program } \\
\text { and received flaxseed extract } \\
\text { (No. } 8 \text { rats) }\end{array}$ & $0.90 \pm 0.37$ & $19.72 \pm 5.85^{* \dagger}$ \\
\hline $\begin{array}{l}\text { VIII; Diabetic rats practiced swimming program } \\
\text { and received cinnamon extract } \\
\text { (No. } 8 \text { rats) }\end{array}$ & $1.42 \pm 0.548^{\dagger}$ & $11.09 \pm 6.94^{\$ \dagger}$ \\
\hline $\begin{array}{l}\text { IX; Diabetic rats practiced swimming program } \\
\text { and received both flaxseed and cinnamon extract } \\
\text { (No. } 8 \text { rats) }\end{array}$ & $1.83 \pm 0.45^{\dagger}$ & $10.13 \pm 7.28^{\dagger}$ \\
\hline
\end{tabular}

$\mathrm{p} \bullet$ vs. group I, $\mathrm{p}^{*}$ vs. group II, $\mathrm{pX}$ vs. group IV, $\mathrm{p} \dagger$ vs. group $\mathrm{V}, \mathrm{p} \$$ vs. group III.

\section{DISCUSSION}

When diabetic rats practiced swimming program, There were insignificant differences in body weight at all intervals and the level of food consumption was lower than it at all intervals except at the beginning and at the end of $2^{\text {nd }}$ week intervals but still higher than control practiced swimming program group at the end of $2^{\text {nd }}, 4^{\text {th }}$ and $8^{\text {th }}$ weeks. These results were in agreement with Hassanpour et al. (2017) who considered exercise a corner stone in diabetes management, increase insulin sensitivity and decrease food consumption by encouraging antioxidant property. However, the results were not in agreement with Frigero et al. (2017) who considered antioxidant property of exercise not sufficient alone to control food consumption.

When diabetic rats practiced swimming program and received flaxseeds extract, the body weight significantly increased at the end of $4^{\text {th }}$ and $6^{\text {th }}$ weeks, and the level of food consumption decreased at all intervals except at the beginning. On comparing to the control- received flaxseeds extract, there was a significant decrease in body weight at the beginning and end of 2 nd week's intervals and significant increase in food consumption at the end of $2^{\text {nd }}$ and $6^{\text {th }}$ weeks.

These results were in agreement with Hasaniani et al. (2019) who stated that the underlying mechanisms of the antidiabetic effect of lignin's present in flaxseeds involve enhancing glycemic 
control, increasing the insulin sensitivity, decreasing food consumption on long run. They stated that flaxseeds contain considerable amounts of vitamin $\mathrm{E}$, primarily as $\gamma$-tocopherol that increases sodium excretion in the urine. This may help lowering body weight, and reported that the flaxseeds could induce satiety and reduce energy intake due to its high content of fiber. Fiber derived from flaxseeds increases transit time and delays gastric emptying. Regular intake of flaxseeds fiber in a low-energy beverage prior to each meal may aid to maintain or lose weight. Another reason may be due to the impacts of isoflavones and lignans on energy metabolism. Also, phytoestrogens have been shown to inhibit the activity of several enzymes involved in cell-signaling pathways and nuclear mechanisms such as cell proliferation and differentiation.

Rezaei et al. (2020) stated that flaxseeds fiber may induce higher postprandial satiety and fullness without affecting ghrelin, cholecystokinin, glucagon like peptide-1, and energy intake. Omega-3 fatty acids decrease adipocyte lipogenesis and stimulate fatty acid mobilization from adipose tissue. Moreover, omega-3 fatty acids decrease adipocyte lipoprotein lipase and increase muscle lipoprotein lipase, resulting in prevention of fat deposition in adipose tissue and augmentation of fatty acid oxidation in muscle and fat depots, the latter through increasing mitochondrial biogenesis in white adipose tissue.

When diabetic rats practiced
swimming program and received
cinnamon extract, insignificant changes
occurred in body weight at all intervals,
and there was a significant decrease in

food consumption from the end of 4th week up to the end of experiment. However, there was significant decrease in food consumption when compared with control-received cinnamon extract, at the end of all intervals except the beginning one. Results of Kassaee et al. (2017) were compatible with the present results, and owed this to ability of cinnamon extract to make insulin-like biological and antioxidant activities and improving oxidative stress, total antioxidant capacity, inflammatory insulin sensitivity and insulin resistance in diabetes, hence decrease food gain. On the other hand, Hosni et al. (2017) stated that cinnamon intake affects advanced glycation end products, antioxidant capacity, and inflammatory markers, not insulin sensitivity or food consumption.

When diabetic rats practiced swimming program and received both flaxseeds and cinnamon extract. There was an increase in body weight at the end of 4th week interval only, and food consumption showed significant decrease at the end of all weeks except the beginning and end of $2^{\text {nd }}$ week intervals, and the effect of combination was more potent than each one alone. Salima et al. (2018) stated that combined effect of herbals is more potent than each one alone due to combined anti-oxidant effect and high efficacy on reduction of insulin resistance, and improve cell glucose uptake and increase body weight. Talaei et al. (2017) and El-Ghawet et al. (2019) mentioned that the effect of hypoglycemic drugs were more potent than herbals in affecting blood glucose level and hence satiety and food consumption. 
When the diabetic rats practiced swimming program, the level of fasting plasma glucose level decreased, and fasting insulin increased without significant change in HBA1c, but fasting glucose level still higher and fasting insulin level lower than control practiced swimming program. Harriss et al. (2018) stated that exercise improves glucose uptake and decreases insulin resistance as exercise initiates several signaling cascades for glucose uptake in muscle, stimulates the translocation of GLUT4 from the cell interior to the cell surface and improves antioxidant defenses. Exercise increase glucose uptake to the operating muscles. Cronin et al. (2017) stated that physical exercise, along with a proper diet, is a central factor in the control of blood sugar and insulin level. But the results disagreed with Mora et al. (2018) who stated that after exercise exhaustion of pancreatic beta cells occurs leading to decrease insulin level.

When diabetic rats practiced
swimming program and received flaxseeds extract or cinnamon extract or both, the fasting plasma glucose level was lower, and insulin level was higher than diabetic group without change in HBA1c but still away from normal level, and the effect of combination was better than each one alone. The results were in agreement with Hasaniani et al. (2019) who stated that flaxseeds decrease blood sugar by improving insulin action at the cellular level when compared with groups not receiving flaxseeds, but needs long periods to affect HBA1c. The mechanism is that flaxseeds up surged the insulin level, and restored the enzymatic antioxidant barrier. Flaxseeds decrease the blood-glucose levels through its components by down-regulation of tumor necrosis factor- $\alpha$, IL- 6 , monocyte chemoattractant protein -1 , interferon- $\gamma$, and nuclear factor kappa-B, and diminishing the pro inflammatory cytokines and vascular infiltration. It also decreases postprandial glucose by enhancing the level of omega-3 fatty acids in plasma and erythrocytes and controls the secretion of a glucagon-like peptide-1 by activating the extra cellular signal regulated kinase pathway, thereby enhancing the secretion of insulin. It has a role in decreasing circulating levels of leptin. The results disagreed with Saed et al. (2019) who stated that flaxseeds need long periods of time to affect insulin or blood sugar longer than time of the experiment because control of glucagon-like peptide-1 secretion by flaxseeds extract supplementation needs above three months at least.

Iqubal et al. (2019) showed that cinnamon acts as antioxidant, potentiates insulin action, and may be beneficial in the control of glucose intolerance and diabetes as well as reducing cardiovascular disease, and improves cognitive function through cinnamaldehyde which reduce lipopolysaccharide - induced nuclear factor kappa B transcriptional activity through the inhibition of DNA binding activity in macrophages. Cinnamon has an ability to enhance insulin signaling by increasing glucose uptake by cells and increase phosphorylation of insulin receptor. Cinnamic acid and flavonoids in cinnamon extract act on increasing insulin signaling pathway, stimulation of insulin secretion, delay of carbohydrate digestion and glucose absorption, improve pancreatic $\beta$-cell functionality, enhance 
glucose uptake and inhibit hepatic gluconeogenesis, protein glycation and insulin fibrillation. The presence of Methyl- hydoxy-chalone polymer in cinnamon successfully mimics the effect of insulin and triggers insulin synthesis via the activation of glycogen synthase and inhibition of glycogen synthase kinase-3 $\beta$ activity. Cinnamon increases the amount of GLUT4 receptors. El-Beeh et al. (2019) stated that the cinnnamaldehyde metabolite of cinnamon was found to manage insulin release, enhance insulin sensitivity, and regulate the protein-tyrosine phosphatase $1 \mathrm{~B}$ and insulin receptor kinase.

Loren et al. (2018) stated that combined effect of herbals is more potent than each one alone due to combined antioxidant effect and high efficacy on improving insulin resistance, and that herbal medicines with strong antiinflammatory and hypoglycemic properties routinely generate attention for a possible role in the management of diabetes mellitus. Ahmad et al. (2020) added that combination of herbals achieve glycemic control in a short period with small doses to avoid side effects of each one alone. Talaei et al. (2017) and ElGhawet et al. (2019) mentioned that the effect of hypoglycemic drugs were more potent than herbals in affecting blood glucose level. Hence, blood sugar and insulin levels and the lack of physicianpatient communication with regard to the use of herbal products as well as the possible drug-drug interactions are some of limitations.

When diabetic rats practiced swimming, the level of cholesterol was lower and HDL was higher than its level in diabetic group without change in T.G. and LDL. Bastuga and Ficicilara (2019) stated that, during exercise, an increase in the uptake and utilization of glucose occurs, and it seems to be dependent on the intensity and duration of the effort, which leads to cholesterol lowering effect on long term by glycemic control, and also increased lipolysis and decreased adipocyte size with direct response to exercise. Tzimou et al. (2019) showed that exercise alone has a little effect on cholesterol level as it needs to be combined with hypoglycemic drugs to achieve tight glycemic control and improve dyslipidemia in long term, and stated that exercise decrease all lipid profile with HDL decreasing. There was no discrepancy as his study done on obese rats which destroy normal metabolism of lipid, and they done different exercise protocols.

When diabetic rats practiced
swimming program and received flaxseeds extract or cinnamon extract or both, the level of cholesterol, LDL and T.G. decreased, but HDL increased as compared to diabetic rats, but not reaching the level of control groups and the combination was more potent indicating higher efficacy of exercise with extracts in improving lipid profile than each one alone. These results were in agreement with Soltanian and Janghorbani (2018) who proved that flaxseeds are rich source of soluble fibers, aspartic acid, glutamic acid and arginine which have cholesterol lowering effects. Flaxseeds increase bile acid synthesis causing cholesterol lowering effect. Enterodiol and enterolactone were effective antioxidants against DNA damage and lipid peroxidation. 
Kassaee et al. (2017) stated that the antioxidant activities of cinnamon bark, leaf and fruit extracts and essential oils have positive effects on lipid metabolism. Cinnamon increases gene expression of proteins responsible for fatty acid metabolism and energy consumption regulation. Salima et al. (2018) stated that a methyl hydroxy chalcone polymer derived from cinnamon enhanced the glucose uptake, glycogen synthesis and phosphorylation of insulin receptor in adipocytes. Thus cinnamon was suggested to act as insulin mimetic and has lipogenic effect.

Jáuregui et al. (2017) and Kaur et al. (2018) were in line with these results as they stated that the combined effect of exercise with cinnamon and flaxseeds is potent than each one alone due to the effect of mega-3 oil in flaxseeds, positive effects on lipid metabolism of cinnamon, and the increase in uptake and utilization of glucose in exercise, and stated that each herbal have been used separately as herbal remedies since many years, and the coadministration of both herbs in reduced doses lead to better and cost effective management alternative for diabetes and related complications such as hyperlipidemia.

When diabetic rats were exposed to swimming program, the MDA level decreased but still higher than control rats, and no significant change in GSH. Harriss et al. (2018) stated that exercise training induces several benefits by reducing inflammation, improving antioxidant defenses, increase levels of reduced glutathione (GSH), decrease in oxidized glutathione, and MDA by increasing number of mitochondria to compensate energy needed for regular exercise. So, each mitochondria has a lower oxidative load, and each mitochondria produces less pro-oxidants. Another mechanism was enhanced enzymatic anti-oxidative systems by regular exercise. Bastuga and Ficicilara (2019) stated that exercise increases oxidative stress and disrupts homeostasis. Thus, training can have positive or negative effects on oxidative stress depending on training load, training specificity, and basal training level.

When diabetic rats practiced
swimming program and received flaxseeds extract, the MDA level decreased, but still higher than control received flaxseeds extract, and no significant change in GSH. On receiving cinnamon extract or both, GSH increased and MDA decreased, but MDA still higher and GSH still lower than the normal value. The effect of combination was more potent than each one alone.

Afzal et al. (2020) stated that the main physiological benefits of flaxseeds are attributed primarily to the high linoleic acid content which contributes to their antioxidant properties against diseases including atherosclerosis, diabetes, hypertension, anti-inflammatory, and anticarcinogenic effects. The results disagreed with Saed et al. (2019) who mentioned that supplementation with flaxseeds or flaxseeds-derived lignin's improve glucose regulation and insulin sensitivity. Flaxseeds have cardio-protective role through improved arterial compliance as well as anticoagulant properties but no obvious anti-oxidant properties.

Dou et al. (2018) showed that cinnamon improves antioxidant capacity with decreasing MDA levels by stimulates 
antioxidant enzymes activities, including superoxide dismutase and catalase, and activating nuclear factor 2. Cinnamaldehyde reduces lipopolysaccharide induced nuclear factor kappa B transcriptional activity through the inhibition of DNA binding. Rajabi et al. (2018) considered that taking cinnamon in human for six weeks did not have any significant effect on MDA levels but needs prolonged periods to reflect the anti-oxidant effect.

Hasaniani et al. (2019) owed the present study to synergism of herbals by activation of certain enzymes like cytochrome p450, enhancing mitochondrial activity and reducing the oxidative stress load, and increasing number of mitochondria hence decreasing its oxidative stress load.

\section{CONCLUSION}

Exercise with receiving flaxseeds extract or cinnamon extract in adult male diabetic rats improved body weight, glucose, insulin level, lipid profile, oxidative stress markers and tissue pathology, and the combination was more potent than each one alone.

\section{REFERENCES}

1. Afzal, U., Butt, M., Ashfaq, F., Bilal, A. and Suleria, H. (2020): Bioassessment of flaxseed powder and extract against hyperglycemia. Biomed. Res. Int., 12: 20-50.

2. Ahmad, A., Khan, A., Batool, Z., Hassan, M. and Khaliq, S. (2020): Medicinal effects of saffron and chamomile on diabetes mellitus and associated hyperlipidemia and memory impairment. Pak. J. Pharm. Sci., 33(3): 1191 1198.

3. Asano, R., Sales, M., Browne, R. and Moraes, R. (2014): Acute effects of physical exercise in type 2 diabetes; A review. World $\mathbf{J}$. Diabetes, 5 (5): 659-665.
4. Bastuga, M. and Ficicilara, H. (2019): Effects of exercise training on anxiety in diabetic rats. Behavioral Brain Research, 376:11- 84 .

5. Cronin, O., Keohane, D., Molloy, M. and Shanahan, F. (2017): The effect of exercise interventions on inflammatory biomarkers in healthy, physically inactive subjects. A systematic review. QJM, 7: 1-12.

6. Dou, L., Yahong, Z., Li, L., Gui, X. and Chen, Y. (2018): The effect of cinnamon on polycystic ovary syndrome in a mouse model. Reprod. Biol. Endocrinol., 6: 2-10.

7. El-Beeh, M., Fouda, Y., El-badry, D. and ElSayyad, H. (2019): Anti-apoptic activity of cinnamon on some organs of 18 days rat fetuses of diabetic mother. Biosciences Biotechnology Research Asia, 16 (3): 637-648.

8. El-Ghawet, H., El-Sayyad, H., Ghanem, N. and Mkhemar, S. (2019): Cinnamon and ginger combined extract in improving diabetes. Iranian J. of Dia. and Obesity, 9 (3): 101-106.

9. Frigero, M., Santos, S., Serra1, A., et al., (2017): Effect of photobiomodulation therapy on oxidative stress markers of gastrocnemius muscle of diabetic rats subjected to highintensity exercise. Lasers in Medical Science, original article, 3: 12-13.

10. Harriss, D., Macsween, A. and Atkinson, G. (2018): Standards for ethics in sport and exercise science research. International Journal of Sports Medicine, 38:1126-1131.

11. Hasaniani , N., Rahimlou, M., Ahmadi , A., Khalifani , A. and Alizadeh, M. (2019): The effect of flaxseed enriched yogurt on the glycemic status and cardiovascular risk factors in patients with type 2 diabetes mellitus: Randomized, Open-labeled, Controlled Study. Clin. Nutr. Res., 8 (4): 284-295.

12. Hassanpour, G., Hosseini, S., Keikhosravi, F. and Noura, M. (2017): The effect of swimming training with cinnamon extract on hematological factors in diabetic rats. Iranian J. of Dia. and Obesity, 9 (3): 101-106.

13. Hosni, A., Moneim, A., Abdel-Reheim, E. and Mohamed, M. (2017): Cinnamaldehyde potentially attenuates gestational hyperglycemia in rats through modulation of 
PPARgamma, pro inflammatory cytokines and oxidative stress. Biomed Pharmacotherapy, 88: 52-60.

14. Iqubal, A., Ali, A, Singh, A. and Kumar, A. (2019): Comparative nephroprotective effect of cinnamomum cassia and zingiber officinal on diabetic rat. Clinical Nutrition, 9 (12): 224 555.

15. Jáuregui, K., Aranda, C. and Herrera, A. (2017): Utricular hypofunction in patients with type 2 diabetes mellitus. Acta Otorhinolaryngol. Ital., 37: 430-435.

16. Kassaee, S., Goodarzi, M. and Oshaghi, E. (2017): Reno-protective effects of trigonella foenum and cinnamon on type 2 diabetic rats. Avicenna Journal of Medical Biochemistry, 5 (1): 17-21.

17. Kassaee, S., Goodarzi, M. and Oshaghi, E. (2017): Reno-protective effects of trigonella foenum and cinnamon on type 2 diabetic rats. Avicenna Journal of Medical Biochemistry, 5 (1): 17-21.

18. Kaur, G., Invally, M., Khan, M. and Jadhav, P. (2018): A nutraceutical combination of cinnamomum cassia and nigella sativa for type 1 diabetes mellitus. J. Ayurveda Integr. Med., 9: 27-37.

19. Kaviarasan, S., Naik, G. and Gangabhagirathi, R. (2015): In vitro studies on anti-radical and anti-oxidant activities of fenugreek (Trigonellafoenumgraecum) seeds. Food Chem., 103 (1): 3-7.

20. Loren, D., Roscoe, R. and Shack, A. (2018): Complementary and alternative medicine for diabetes. Canadian Journal of Diabetes, 42: 154-161.

21. Mora, A., Kayacanb, Y., Ipekoglua, G. and Arslanoglua, E. (2018): Effect of carbohydrate-electrolyte consumption on insulin, cortisol hormones and blood glucose after high-intensity exercise. The Journal of Metabolic Diseases, Archives of Physiology and Biochemistry, 1: 2-30.
22. Rajabi, G., Mohaddes, F., Farajdokht, S., Nayebi, M. and Mesgari, S. (2018): Impact of loganin on pro-inflammatory cytokines and depression- and anxiety-like behaviorsin male diabetic rats. Physiol. Int., 3: 199-209.

23. Rezaei, S., Sasani, M., Akhlaghi1, M. and Kohanmoo, A. (2020): Flaxseed oil in the context of a weight loss program ameliorates fatty liver grade in patients with non-alcoholic fatty liver disease: a randomized double-blind controlled trial. The British Journal of Nutrition, 3: 34-89.

24. Saed, L., Deihim, Z., Naghshbandi, M., Rajabnia, M. and Naleini, S. (2019): Cardiovascular events in patients with over 10 year's history of type 2 diabetes mellitus. Diabetes Metab. Syndr., 13: 68-72.

25. Salima, B., Saidb, G., Noureddine, M. and Allali H. (2018): Molecular modeling interaction between enzyme diabetes type 2 dipeptidyl-Peptidase (DPP-4) and main compound of cinnamon current enzyme inhibition. Clinical Nutrition, 14: 61-66.

26. Soltanian, N. and Janghorbani, M. (2018): A randomized trial of the effects of flaxseed to manage constipation, weight, glycemia, and lipids in constipated patients with type II diabetes. Nutrition \& Metabolism, 2: 15-36.

27. Talaei, B., Amouzegar, A., Sahranavard, S., Hedayati, M., Mirmiran, P. and Azizi, F. (2017): Effects of cinnamon consumption on glycemic indicators, Advanced J. of Met., 4: 12-18.

28. Tzimou, A., Taitzoglou, I., Galazoulas, C. and Mougios, V. (2019): Effects of physical exercise and social isolation on anxiety related behaviors in two inbred rat strains. Behavioural Processes J., 142: 70-78. 


\section{در اسة تأثير التمرينات العضلية مع مستخلص القرفة مع أو أو التون بدون مستخلص بذور الكتان في ذكور الجرذان البيضاء البالغة المصنابة بداء السكري في فئوري}

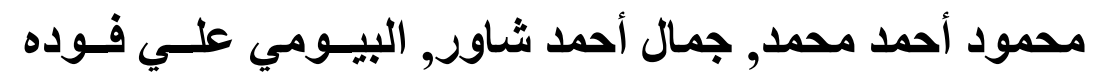
قسم الفسيولوجيا الطبية, كلية الطب, جامعة الازهر

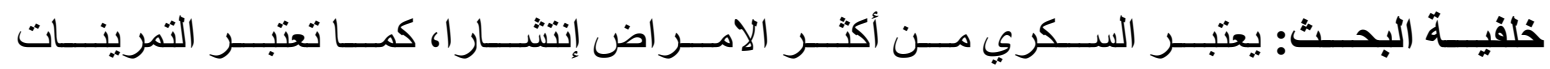

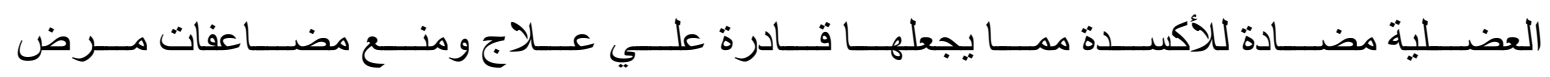

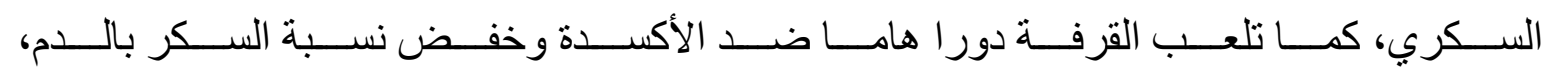

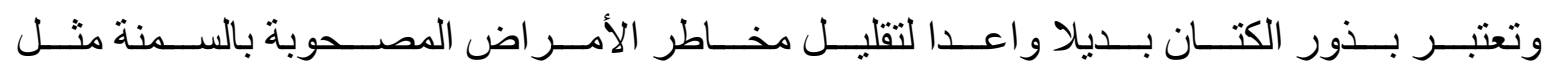
مرض السكري.

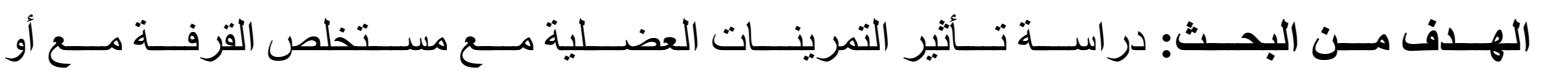

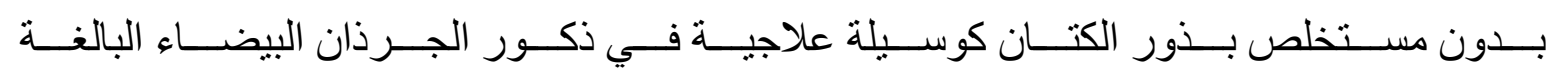
و المصابة بداء السكري.

مــواد وطــرق البحــث: تــم عمــل الدر اســـة علــي إثتــين وســبعين مــن ذكــور الجــرذان

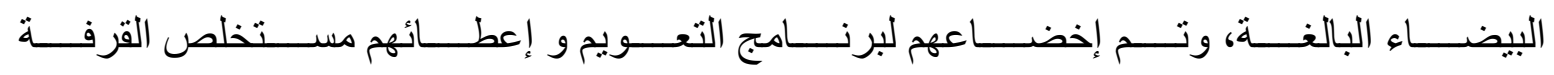

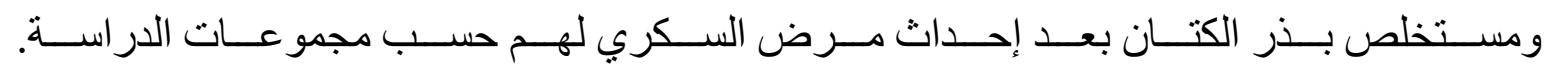

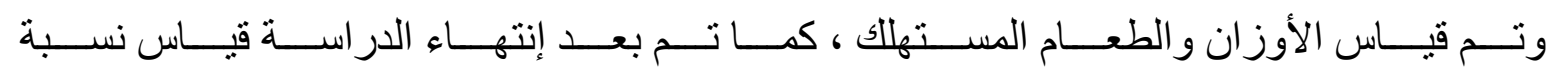

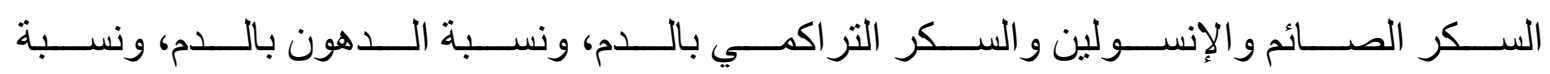
الجلوناثيون المختزل و المالون داي الدهيد، وفحص عينات الهرنتوباتولوجي.

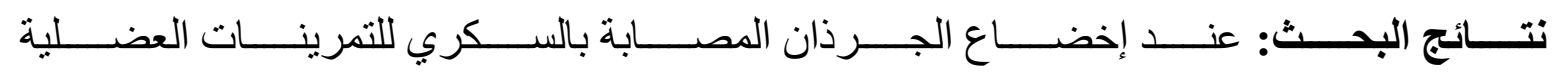

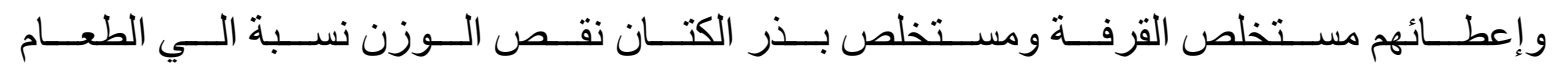

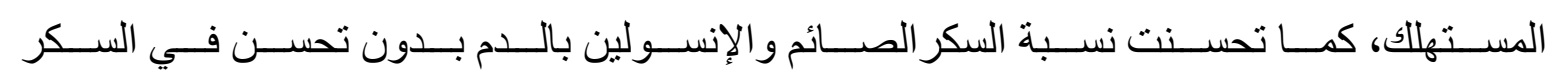

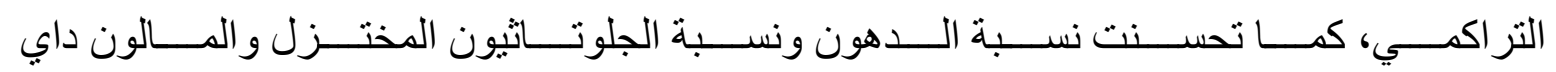

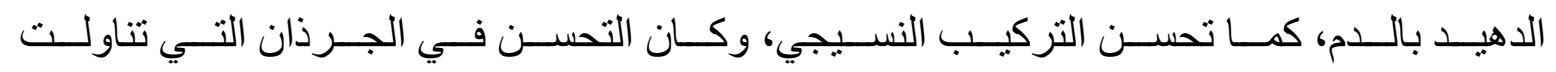
كل من مستخلص القرفة وبذور الكتان معا أكبر من المجمو عات الاخري. 


\section{MAHMOUD AHMED MOHAMED et al.,}

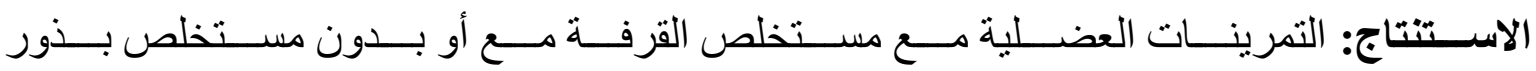

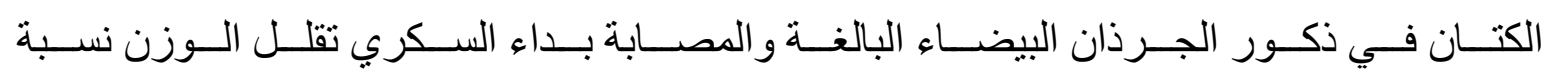

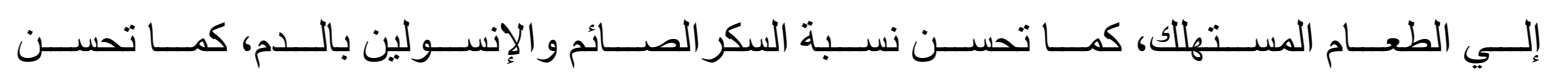

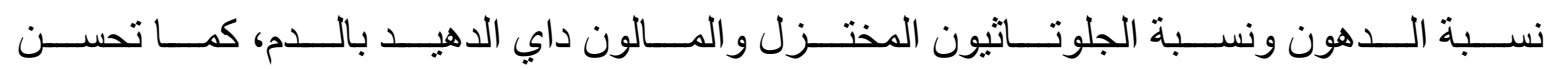

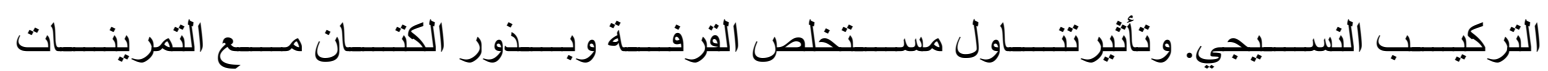
العضلية أكبرمن كل علي حدة. 